\title{
PROFESSIONALISMS OF FEMALE WORKERS IN THE INFORMAL SECTOR AT THE CITY OF PALEMBANG, INDONESIA
}

\author{
Taufik Mirna*, Monanisa, Armansyah, Lecturers \\ Geographic Study Program, PGRI University of Palembang, Indonesia \\ Nengyanti, Soebyakto Bambang Bemby, Lecturers \\ Demographic Study Program, University of Sriwijaya, Palembang, Indonesia \\ *E-mail: mirnaputridata@yahoo.com
}

\begin{abstract}
Economic pressures often require women to decide to work for additional household income. Their multiple roles in family, community, and workforce create a factor that makes them particularly interested in the informal sector. This study was designed to determine the professionalism of female workers in the informal sector by surveying 300 respondents at the City of Palembang, Indonesia. The data obtained were analyzed by a descriptive statistical method, namely, frequency analysis, and presented in tables and pie charts. The results showed that female workers in the informal sector did not prioritize professionalism at work; instead, they simply relied on their daily food preparation skills to open food stalls and sell snacks, beverages, and other tradable foods. Meanwhile, other female workers skilled in sewing and cosmetology preferred selling products to offering sewing services or opening beauty salons. These skills were mostly acquired by self-study (40 percent), and a few of them were developed from passed down information in families ( 26 percent), training organized by the government (19 percent), and the internet (3 percent).
\end{abstract}

\section{KEY WORDS}

Professionalism, workforce, women, informal sector, economy.

The high participation of women to work, especially in the informal sector, is neither taboo nor negative affair (Armansyah and Mirna 2018) but an ordinary economic reality in society, mainly in developing countries like Indonesia (Rahman, Bhattacharya, and Al-Hasan 2019). Given the inability of employers to absorb the current large number of workers, the employment sector has given a major economic problem to the country (Todaro and Smith 2011).

Initially, married women had the responsibility of only taking care of their children and husbands in domestic life (Bhasin 1996), but in today's modern life, they have acquired other roles (Dewi 2012). As times have changed to acknowledging gender equality, women now have the opportunity to be part of the workforce. Increased necessities of life after marriage encourage them to work and help improve the family's economy. Artini (2009) mentions that one of the reasons women work is to help earn higher family income by engaging mostly in the informal sector.

This sector is often called an underground economy because it includes all activities starting from within a household up to works that intentionally avoid taxes and various economic activities that do not follow legal, economic practices, e.g., business licenses and tax compliance (Dieter 1991). The nature of its businesses is more synonymous with laborintensive, competitive, and privately owned and controlled enterprises that make use of local sources of raw materials and develop their skills and technology personally (Leys 1974). Even Mazumbar (The World Bank in Kuncoro, 2000) claims that the informal sector is any type of business whose activities lack or have minimal intervention and protection from the government. In more detail, Hidayat (1990 in Lamba 2011) characterizes the informal sector with irregular activities, no government intervention, small capital, simple equipment, profits that are only sufficient for daily needs, non-permanent place of business, no interrelation with 
other business sectors, practices focused on providing production goods for the lower to the middle class, and types of work that do not require special skills and largely depend on social capital (Kebede 2018).

When the development program designed by the government is deemed less capable of employing job seekers, especially women, the informal sector becomes the most rational choice to earn some money to survive in urban areas. According to Wahyuni (2005), the informal sector has always been one of the alternative jobs for workers in Indonesia. In the event of economic crises, layoffs, and unemployment, the sector offers income-generating activities that sustain the lives of its workers.

Life in urban areas with all population-related problems is an issue that must be handled wisely. In a densely occupied area with limited job availability, people with low educational background and skills are forced to engage in an informal economy. They tend to choose the employment sector that is relatively easy to enter (Armansyah and Aryaningrum 2018). Types of work that do not require special skills and higher education in urban and rural areas mostly belong to the informal sector. Farinmade, Soyinka \& Siu (2018) suggest that in urban areas, the sector includes any social, economic, and physical activities in a particular geographical area with no tax levied on them.

Apart from the absence of specific educational and skill requirements, the informal sector also offers time flexibility that allows it to absorb many job seekers and the unemployed. This flexibility of time creates opportunities for female workers to juggle work and household care more time-efficiently (Wulantari and Armansyah 2018). For this reason, women are not only homemakers but also secondary earners. Moreover, women who work in the informal sector are quite commonly the primary earner or breadwinner in the family, and the income they generate is used for daily living needs and expenses (Mohapatra 2012). However, due to the unregistered status of the informal sector, female workers are often victims of violence and abuse (Matlon 2011).

In general, the informal sector involves activities carried out by the middle to the lower class and small-sized enterprises. Due to minimal education, low skills, and personally arranged work time that typify the sector, a standardized benchmark is not available to improve and develop businesses. Moreover, nearly all people working in this subsistence sector do not have skills in their fields apart from the courage to open food stalls, sell cakes and beverages, and start other small enterprises in the first place. In low economic society, these characteristics may be problematic and increasingly uncertain unless the government responds immediately and efficiently. Therefore, informal-sector workers, especially women, are inclined to experience an even greater and more complex problem, and any enterprises in the sector cannot develop properly. On the other hand, groups of people deify this sector, especially those coming from low-income households with inadequate educational background and skills, because it is a vital means by which their family can sustain economically.

\section{METHODS OF RESEARCH}

This study used a survey method with a total of 300 female respondents working in the informal sector at the City of Palembang. The data obtained were analyzed with frequency analysis and presented in tables and pie charts, and the results were discussed with previous relevant studies or theories as a reference to support the findings in the field. Quantitative methods are intended to describe the identified condition or situation more objectively. Population agglomeration and concentration of business activities were the main reasons for selecting the City of Palembang as a focus in this research.

\section{RESULTS AND DISCUSSION}

Professionalism is the conduct that characterizes people who are an expert in their field and rely on their expertise to make better the economic situation of themselves and their 
families. In this research, the analysis and discussion of professionalism are focused on skills and sources of skills that female workers in the informal sector possess.

The willingness of women to work at present is very complex, especially because working is often a resort to improving the economic situation of the family. Job seekers must possess specific skills as the benchmarks of income-generating activities, especially for women who have multiple roles. Women who decide to work must be able to arrange the time to involve themselves at work and household affairs.

Since the informal sector provides opportunities for better time management, women can work from home using small capital and conduct economic activities that do not require high formal education. Flexibility is known to be the primary key of workers deciding to work in the informal sector (Soebyakto and Armansyah 2016; Armansyah, Sukamdi, and Pitoyo 2019). Furthermore, Rini (2012) states that so far, the sector has significantly contributed to absorbing labor, overcoming unemployment, and changing the employment statistics. For productive economic activity, some specific skills are required. However, female workers in this sector have fewer skills to support professionalism in their fields.

The results showed that the skills of female workers in the informal sector were cooking (63 percent), trading products (23 percent), sewing (9 percent), and make-up and beauty treatments ( 5 percent). In other terms, they do not prioritize professionalism at work but simply rely on their daily food preparation skills to open food stalls and sell cakes, drinks, and other tradable foods. Pragmatically, this finding illustrates one of the characteristics of the informal sector that mostly absorbs low-skilled labor (Mughal and Schneider 2020).

The modest trading skills possessed by women in the informal sector decrease the quality of the packaging of merchandise, trading system, and service system to consumers, resulting in low productivity. Some of the sampled female workers who had skills in sewing and cosmetology would instead engage in trading products than opening a beauty salon and offering their sewing services. This situation is the result of the high financial capital required to start a beauty salon and a tailoring stall. On the contrary, cooked food can be sold at or from home with much smaller capital because the equipment used is quite simple and can be found daily in the kitchen. According to (Pitoyo 2007), the informal sector is characterized by independent businesses, modest equipment/technology, minimal capital, and unorganized and unregistered enterprises.

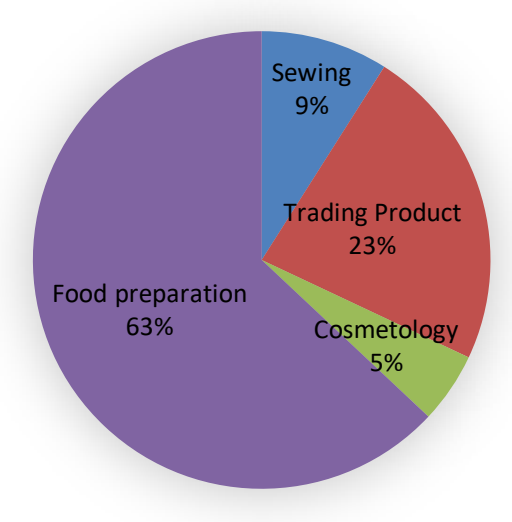

Figure 1 - The Percentage of Female Workers in the Informal Sector by Skills

(Source: Field Data Analysis, 2019)

Lack of skills among female workers in the informal sector leads to low professionalism. Ideas for engaging in trading activities arose not due to innovations but rather because informal workers wanted to imitate newly introduced or trending products in the community. Therefore, tight competition among sellers often leads to the closedown of some stalls and force the owners to start another business. However, due to the lack of skills and creativity, female workers in this situation are inclined to repeat the same economic activities. 
Workers with low skills typify the informal sector, and this is the main reason why they mostly experience significant obstacles in developing their enterprises and competing with other similar workers while trying to improve their economic situations (Armansyah and Aryaningrum 2017). Some informal workers are skilled in trading products, cooking or food preparation, sewing, and make-up and beauty treatments. Based on the results of the interviews, the majority of female workers had self-taught skills (40 percent), while only a few of them acquired their skills from families (26 percent), training organized by private or governmental agencies (19 percent), and the internet (3 percent).

These results indicate that the government has also implemented some interventions in skills improvement, even though they are relatively lower than the role of families in helping female workers to acquire the necessary skills. With this finding, increased involvement of the government is highly suggested, mainly to provide training and improve the quality of the informal-sector workers. It is also consistent with the fact that the sector has become the primary destination for female workers with low education and skills to earn income. According to Dinkelman \& Ranchhod (2012), in addition to low formal educational attainment, informal-sector workers are also dominated by females. Therefore, this sector is often predicated as consisting of small and unproductive economic activities that are difficult to develop (Pitoyo 1999). This assertion will continue to stick as long as the workers in this sector still have categorically low quality.

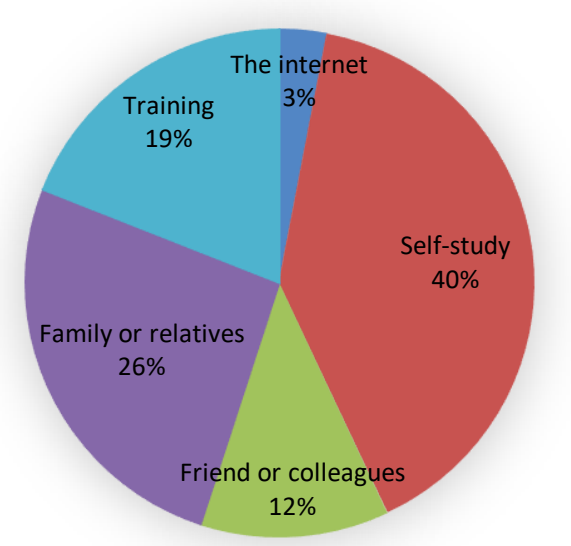

Figure 2 - The Percentage of Female Workers in the Informal Sector by Sources of Skills (Source: Field Data Analysis, 2019)

Apart from the self-taught skills, female workers in the informal sector also developed their experience in product trading and food preparation from other sources. Some skills were acquired with the assistance of friends or colleagues and from information widely shared on the internet. With current technological advancement, female workers can use the internet as a tool to develop their skills in trading and cooking.

Even though the government constituted only 19 percent of the source of skills observed in this study, this finding confirms that the government has participated in increasing the productivity of the informal sector (Rahman et al. 2019). Through the intervention of policymakers, the economic capacities and skills of female workers in the sector are expected to improve in various ways, raising their competitiveness in the community. In this context, government intervention is intended to enhance the professionalism of the community in product trading so that they can earn a decent income or even change their employment sector from informal to formal. This purpose is in line with one of the objectives of the SDGs-2030, that is, to provide opportunities for all male and female workers to obtain decent work and equal pay (SDGs 2017). Increased professionalism is believed to be able to make better the economic situation of families relying on the informal sector and, in the long term, erase the predicate that this sector is limited to small, less productive, and unpromising economic activities. 


\section{CONCLUSION}

The professionalism of female workers in the informal sector in running their businesses is categorically low because they prefer working in the informal sector instead of making use of the specific skills they own (e.g., sewing and make-up and beauty treatments). More often than not, with limited financial capital, they are inclined to resort to working in the informal sector. The majority of female workers in the sector acquire their skills from self-study and family. This finding indicates that the level of skills possessed potentially deviates from the expected standards of working skills. In response to this, routine skills training programs must be conducted to increase the skills of female workers in the informal sector to meet these standards. At the same time, they expect some capital assistance from outside parties, which can later be used to improve their business and skills.

\section{ACKNOWLEDGMENTS}

The authors would like to thank the Directorate of Research and Community Service, the Ministry of Research, Technology and Higher Education, for their financial support in the $2017 / 18$ and $2018 / 19$ fiscal years.

\section{REFERENCES}

1. Armansyah and Kiki Aryaningrum. 2018. "Tantangan Pekerja Wanita Sektor Informal Pada Era Masyarakat Ekonomi ASEAN Di Kota Palembang Sumatera Selatan." Demography Journal of Sriwijaya 5(2):48-56.

2. Armansyah and Kiki Aryaningrum. 2017. "Analisis Karakteristik Demografi Pekerja Wanita Sektor Informal Pada Era Masyarakat Ekonomi ASEAN Di Kota Palembang." Populasi 25(1):52-63.

3. Armansyah and Taufik Mirna. 2018. "Representasi Perempuan Pekerja Migran Menurut Laki-Laki Di Kota Palembang." Populasi 26(1):26-38.

4. Armansyah, Sukamdi, and Agus Joko Pitoyo. 2019. "Informal Sector-A Survival or Consolidation Livelihood Strategy: A Case Study of The Informal Sector Entrepreneurs in Palembang City, Indonesia." RJOAS 11(95).

5. Artini, Ni Wayan Putu and Handayani. 2009. "Kontribusi pendapatan Ibu Rumah Tnagga Pembuat Makanan Olahan terhadap Pendapatan Keluarga." Piramida 5(1).

6. Bhasin, Kamla. 1996. Menggugat Patriarki. Yogyakarta: Bentang.

7. Dewi. Putu M. 2012. "Partisipasi Tenaga Kerja Perempuan dalam Meningkatkan Pendapatan Keluarga." JKT. Vol 5 (2) 119-124.

8. Dieter-Evers, H. 1991. Ekonomi Bayangan Produksi Subsisten and Sektor di Luar Aktivitas Pasar Umum and yang terlepas dari Negara. Jakarta: Prima No.5 1991-LP3ES.

9. Dinkelman, T., \& Ranchhod, V. 2012. "Evidence on the impact of minimum wage laws in an informal sector: Domestic workers in South Africa." Journal of Development Economics 99(1):27-45.

10. Farinmade,A., Soyinka, O., \& Siu, K. W. M. 2018. "Assessing the effect of urban informal economic activity on the quality of the built environment for sustainable urban development in Lagos, Nigeria." Sustainable Cities and Society. Vol. 41: 13-21.

11. Kebede, Getahun Fenta. 2018. "Social Capital and Entrepreneurial Outcomes: Evidence from Informal Sector Entrepreneurs in Ethiopia." The Journal of Entrepreneurship 27(2):209-42.

12. Kuncoro, Mudrajad. 2000. Ekonomi Pembangunan Teori, Masalah and Kebijakan. Yogyakarta: Unit Penerbit and Percetakan Akademik Manajemen Perusahaan YKPN.

13. Lamba, Arung. 2011. "Kondisi Sektor Informal Perkotaan Dalam Perekonomian Jayapura-Papua." Jurnal Ekonomi Bisnis 16(2):155-61.

14. Leys, C. 1974. "Interpreting African Underdevelopment: Reflection on the ILO Report on Employment, Incomes and Equality in Kenya." Manpower and Unemployment Research in Africa, 7(2), 18-28. 
15. Matlon, Jordanna. 2011. "Informality and Visibility on the Periphery." American Sociological Association 10(2):58-63.

16. Mohapatra, K. K. 2012. "Women Workers in informal Sector in India: Understanding the Occupational Vulnerability." International Journal of Humanities and Social Science, 2(21).

17. Mughal, Khurrum S. and Friedrich G. Schneider. 2020. "How Informal Sector Affects the Formal Economy in Pakistan? A Lesson for Developing Countries." South Asian Journal of Macroeconomics and Public Finance: 1-15.

18. Pitoyo, Agus Joko. 1999. "Pedagang Kaki Lima Pada Masa Krisis." Populasi 10(2).

19. Pitoyo, Agus Joko. 2007. "Dinamika Sektor Informal Di Indonesia Prospek, Perkembangan, and Kedudukannya." Jurnal Populasi 18(2):129-46.

20. Rahman, Mustafizur, Debapriya Bhattacharya, and Md Al-Hasan. 2019. "Dimensions of Informality in Bangladesh Labour Market and the Consequent Wage Penalty." South Asia Economic Journal 20(2):224-47.

21. Rini, Hartati Sulistyo. 2012. "Dilema Keberadaan Sektor Informal." Komunitas 4(2):200209.

22. SDGs. 2017. "Sustainable Development Goals." Retrieved on March 27, 2020, from (https://www.sdg2030indonesia.org/).

23. Soebyakto, Bambang Bemby. and Armansyah. 2016. "Migrant Women Working at Informal Sectors: Empirical Study in Kuto Batu Village, llir Timur li Palembang City." International Journal of Humanities and Social Science 6(4):125-37.

24. Todaro, Michael P. and Stephen C. Smith. 2011. Pembangunan Ekonomi. 11th ed. edited by A. N. I. S. Maulana. Indonesia: Erlangga.

25. Wahyuni, D. 2005. "Peran Sektor Informal Dalam Menanggulagi Masalah Pengangguran Di Indonesia." Jurnal Economia. 1 (1): 54-64.

26. Wulantari, Raden Ayu and Armansyah Armansyah. 2018. "Analisis Dampak Kakarakteristik Demografi Pada Perolehan Pendapatan Pekerja Perempuan Sektor Informal Di Kota Palembang." The Journal of Society \& Media 2(1):37-52. 